\title{
Creating Virtual Learning Environment: Shared Online Learning in University Education
}

\author{
Julia Lopukhova, Elena Makeeva \\ Samara State Technical University ${ }^{l}$, \\ Samara State University of Social Sciences and Education ${ }^{2}$ \\ Russia
}

\begin{abstract}
This paper is devoted to the problem of reimagining higher education in Russia. Being a part of the larger international higher education system, Russian higher education is experiencing pressures brought by the rapid technological changes and the integration of the global economies. The development of the information society and the widespread diffusion of information technology give rise to new opportunities for learning. At the same time, they challenge established views and practices regarding how teaching and learning should be organised and carried out. In Russia, University graduates attending traditional face-to-face lectures and seminars lack adequate training, real-world experience and practical knowledge. The paper proposes three innovative practices that can successfully reform and improve the existing system of higher education in Russia: Open Educational Recourses, Shared Online Courses and Massive Open Online Courses. OER includes learning content, software tools to develop, use and distribute content, and implementation resources such as open licenses. While various open learning initiatives have been around for decades, the growth, availability, and popularity of MOOCs are poised to impact public higher education academic models. The MOOC courses benefit from the rising dissatisfaction in the cost and value of a higher education degree creating a watershed moment for higher education. As for Shared Online Courses, leading universities of Russia established the National Open Education Platform Association to develop an eLearning platform with resources open to the members of this Association and, in perspective, to other universities. Gradually introduced into the educational process, these three practices will help create a new effective learning environment in Russia.
\end{abstract}

\section{Introduction}

Our research which is a research in progress as we are planning to carry it out for the next couple of years) is devoted to the problem of reimagining higher education as higher education in Russia today does need significant changes.

Education has long been seen as a crucial tool for national development, with various education initiatives designed to work towards eliminating poverty, increasing the health of a population or enhancing local economies, among others.

Higher education plays an important part in the life of any country as it provides this country with highly-qualified specialists for future development and progress. Nowadays higher education is facing a number of challenges: rapid technological development, population aging (and Russia is an aging society), growing competition between universities both nationally and internationally. Besides, in spite of the financial crisis which has affected the whole world standards of living are steadily changing in Russia. Today's world is vastly different from that of 20 years ago. And the pace of change is accelerating, with increasing globalisation; advances in technology, communications and social networking; greatly increased access to information; an explosion of knowledge; and an array of increasingly complex social and environmental issues. The world of work also is undergoing rapid change with greater workforce mobility, growth in knowledge-based work, the emergence of multidisciplinary work teams engaged in innovation and problem solving, and a much greater requirement for continual workplace learning. Student pressure on universities to help them get good jobs is not new, but it is becoming a greater priority of governments as well. Governments in many countries have for years put pressure on universities to be relevant and responsive to societal needs. This initially focused on applied research and expanding access, but recently, improving employability has been added to the list. University curriculum must attempt to equip students for this significantly changed and changing world. The rising cost of traditional education is another reason for change. While it is clear that higher education systems and institutions worldwide face unprecedented challenges in meeting the increasing 
demand for initial and continuing education, it is also clear that there are developments that will increase access, make learning opportunities more flexible and help contain rapidly increasing costs.

However, many features of university curriculum have been unchanged for decades. We continue to present disciplines largely in isolation from each other, place an emphasis on the mastery of large bodies of factual knowledge and treat learning as an individual rather than collective activity.

This all means that the kind of education, which was good enough twenty years ago, is not good today [12]. This means that styles of teaching, quality of learning materials and university education management have to be brought up-to-date and improved [23]. The time has come to reimagine education.

One of the important issues which has to be settled in Russia is developing connections between universities and business by means of implementing new technologies in education and making education, to some extent, international. Universities focus on educating people and in creating new knowledge and excelling in existing know-how, while companies concentrate on mastering the challenges of a competitive environment and are striving for market success. Current pedagogical approaches are insufficient for preparing students pursuing higher education globally as well as the type of leaders, entrepreneurs, and thinkers that we need for the future. The curriculum of most institutions still focusses on acquiring skills needed to become a researcher or a scholar. What is even worse, most university teachers have no practical experience other than research (and teaching). The vast majority of graduates, however, do not plan to become researchers, nor would they ever become scholars. What they really need is adequate training, real-world experience and practical knowledge. Only with students being well-educated in new methodologies and corporate experts transferring these innovations into practical projects which involve students, it will be possible to see how the collaboration can bring about mutual advantages.

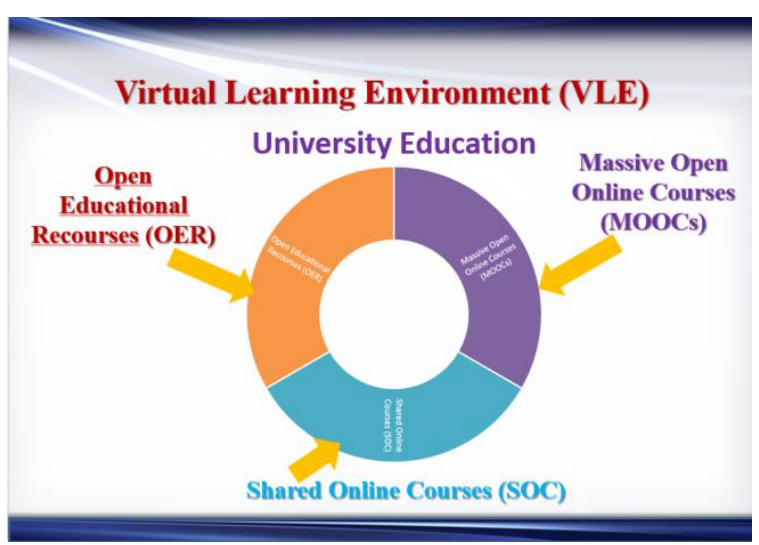

Figure 1. Virtual Learning Environment
We believe that only a balanced combination of well-designed, standardised and evidence-based professional university education with implementation of Open Educational Recourses (OER) together with Shared Online Courses (SOC) and Massive Open Online Courses (MOOCs) can provide a solution to the problems mentioned above. This project can be referred to as "Creating Virtual Learning Environment (VLE)" (see Figure 1).

\section{Current Situation}

\subsection{Global Trends}

The globalisation of the world's economies is leading to increased permeability of national educational boundaries as well as to greater emphasis on the internationalisation of curricula. Internationalisation continues to be on the agenda of higher education providers worldwide. It has significance for the sustainability of higher education at national level and subsequently the contribution that higher education makes to the development of a nation, its people; and its ability to compete in a global market. Developing the ability to be flexible, to adapt to differing contexts, to apply skills and knowledge, to be able to engage with other students who are internationally or culturally diverse - these are all characteristics of students in a successful university of today. Thus, the internationalisation of higher education seems to be a double-edged phenomenon, inducing growing collaboration and growing competition among countries and among institutional providers [2].

Internationalisation takes many forms, including co-taught courses and degrees, online courses, academic faculty exchanges, student recruitment and joint research, collaborative research projects and student exchanges. All this has become possible only recently, with the emergence of the Internet, to a greater part. Today, almost all higher education institutions offer programs that integrate digital media in an online environment to provide flexible learning opportunities, independent of time and place. All of these activities involve reaching out into the international arena in some way and partnering with or communicating with institutions, staff, faculty and students in other countries [9]. This cannot be fully applied to Russia, though. Despite the growth of and further demand for international links and partnerships, there remain a variety of challenges, particularly relevant to its higher educational system. One key barrier is language English in particular. In a phenomenological study of international students at a large public research institution, international students identified language as a key factor in shaping their experiences [16]. Even students who felt they were proficient in the 
English language stated that delivery of the English language in the classroom created challenges.

Therefore, appropriate language skills of faculty and students are required for successful internationalization. In Russia, students and teaching staff in many universities (technical, primarily) either do not speak English at all or their knowledge of English is so poor it cannot be used for academic purposes. This is also the reason why the overall target for internationalisation in Russian universities does not as yet seem to be a matter of government policy.

The second barrier is a financial one as there are very few options for non-European universities to get financial support for either students and academic faculty exchanges or for co-taught courses.

At last, while the internationalisation of the higher education classroom provides many benefits, challenges are also associated with a culturally diverse and rich environment. Each culture that is represented possesses varying expectations, perceptions, and prejudices based upon their cultural norms and experiences. Unless these differences are recognized and addressed, a true globalization of the classroom will not exist. Rather, students from different nationalities will co-exist in the same classroom, but intercultural learning will not occur [8].

\subsection{Russian higher education system and its specifics}

Russia has a long-standing tradition in highquality education for all citizens. The Soviet Union probably used to have also one of the best masseducation systems in the world producing a literacy rate $(98 \%)$ exceeding most Western European countries. Since the dissolution of the Soviet Union in 1991, Russian education system, including compulsory basic education and higher education, has undergone continuous reformation.

The economic and political events of the past decades have had a dramatic effect on every sphere of Russian life, including the education system. These reforms brought new ideological and managerial freedom for universities as well as new opportunities and demands.

In 2003 Russia signed the Bologna Declaration, which launched the process of migrating from Russian traditional tertiary education model to a modern degree structure in line with Bologna Process model. In October 2007 in Russia a law was enacted that replaced the traditional five-year model of education with a two-tiered approach: a four-year bachelor degree followed by a two-year master's degree. In 2010 the admission to the traditional fiveyear programs was stopped. By 2014, in Russia there was no five-year programs students excluding just a few specializations [21].
Thus, a higher education reform aimed at bridging the gap between Russian universities and European universities has already been going on for about 15 years [1]. The situation in higher education is complicated by many problems resulting from Russia's economic difficulties and the transition to a market economy.

As a result, the system of higher education has undergone considerable change in the following areas:

- Goals: with an orientation towards the needs of the market, society, and individuals;

- Structure: decentralization (in contrast to Soviet centralized planning);

- Autonomy of higher educational institutions: introduction of private higher education; four- and two-year programs in parallel with the traditional five-year program; elimination of a bias towards engineering specialties;

- Financing: diversification of financial sources instead of a reliance solely on state financing;

- Content: increasing the humanitarian components in the curriculum, and diversifying programs and courses [21].

The system continues to experience major changes, all connected to the political goal of improving the quality and therefore international competitiveness of the country's universities. Political initiatives focus particularly on the consolidation of the system, which is characterized by a very high number of higher education institutions, many of which do not meet national and international quality standards [25].

The thing is that the network of higher education institutions has experienced significant growth and decline, increasing by almost 200 percent in 19902010 and then decreasing by about 20 percent (see Figure 2). However, a closer look at the data reveals that much of the change comes from the number of non-state higher education institutions which we do not review here [21].

At the moment, the Russian higher education system remains relatively centralized: the Federal Government provides no less than $50 \%$ of all higher education institutional expenditures and keeps all state-owned institutions' funds under strict control through a special system of treasury accounts, it provides accreditation, attestation and licensing of all institutions, private or public, it establishes considerably detailed unified standards of higher educational programs defining the curricula and content for all disciplines and it maintains a monopoly on issuing degree level diploma certificates [14]. 


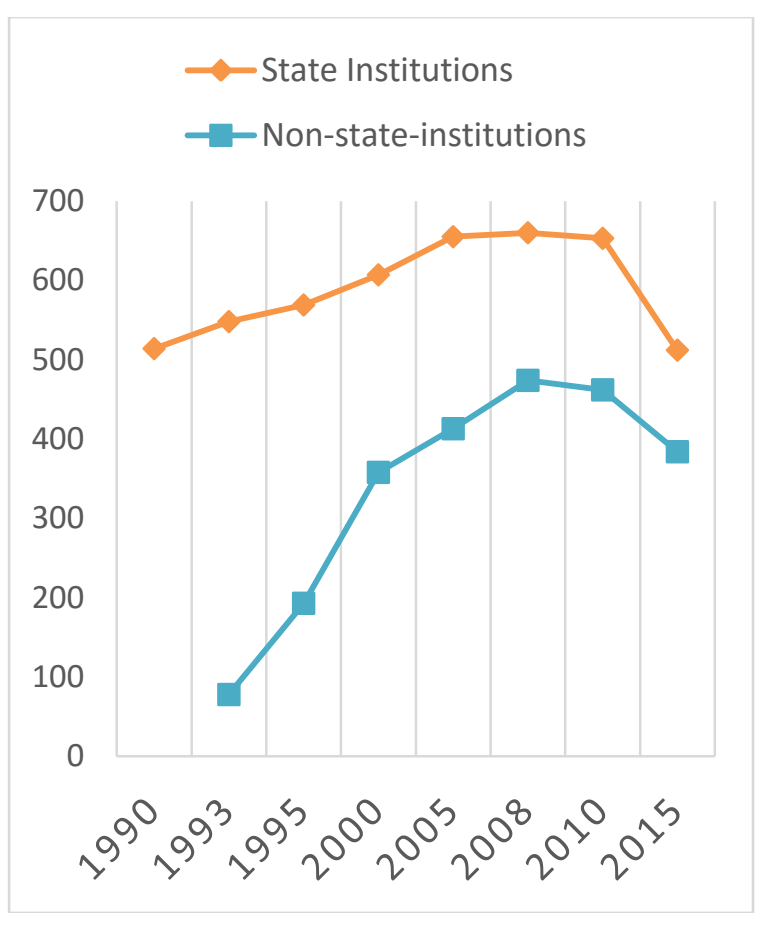

Figure 2. Number of higher education institutions in the Russian Federation and their form of ownership

Though the volume of government spending on higher education has increased over the past years, still it is considerably low as compared with most European countries [21]. Higher education institutions compete for state support from the federal budget but its greater part goes to federal and national research universities leaving regional institutions to survive by themselves. It all lowers chances of Russian students and teaching staff to collaborate successfully with international partners and participate in international programs thus lowering students' chances to successfully compete on the international job market later. Thus, the strategic mission of each university is the formation and development of competitive human capital by creating and implementing innovative education services and practices which involve least expenditure.

In Russia, there are three possible ways of studying at universities and other higher education institutions:

- conventional study: students attend mandatory face-to-face lectures, seminars, practical classes (usually 27-36 hours a week);

- combination of face-to-face and self-study: students attend evening and week-end classes (after $6.00 \mathrm{pm}$ and on Saturdays) at the university 3-4 times a week and combine it with self-study (usually 16 hours a week);
- correspondence study, combined with faceto-face study blocks: twice a year students attend face-to-face sessions including lectures, seminars and exams (max. 200 hours a year).

Thus, online education and eLearning is not considered to be a part of university education at the moment.

On the other hand, significant development of Internet connectivity around the world and proliferation of digital devices give birth to new uses in the field of teaching and learning. And there are strong efforts by the Russian Government, as well as higher education institutions, to increase the range of programs and courses offered online, to improve their quality and to make new forms of education a universally accepted part of university education. The time has come to reimagine education and regional state-budgeted universities have to do it with a minimal expenditure.

\section{Project}

The current pedagogical approaches are insufficient for preparing students pursuing higher education globally as well as the type of leaders, entrepreneurs, and thinkers that we need for the future. The rising cost of traditional education is another reason for change. So are the enormous advances in technology that allow the customization of education to individual learning styles, group learning, online interactivity, gaming and real-time employer projects.

It was decided that, starting in September 2010, new educational standards in higher education would be implemented. As in other levels of education, standards are oriented on learning outcomes written in terms of competences. Universities can independently select half of their courses and curricula, and must offer optional courses in every educational program. Course offerings also are oriented on the independent study of students: up to 50 percent of learning time is reserved for student self-learning. At last, universities have got a chance to decide themselves what is better for their students.

At the same time, technology is becoming central to the process of learning and teaching in higher education and it is also driving wider access to education and training. As societies rapidly develop into knowledge-based information economies, information technology becomes a key driver of both economic competitiveness and social development.

We all know that eLearning and open distance learning has gained momentum around the world as a new, flexible, and dynamic way of acquisition of academic knowledge and professional experience in a complex albeit changing and challenging global environment of the XXI century [13]. But now it is not enough. There are three innovative practices that 
can successfully reform and improve the existing system of higher education in Russia if properly introduced. Thus, we hope to create "Virtual Learning Environment (VLE)" with implementation of Open Educational Recourses (OER) together with Shared Online Courses (SOC) and Massive Open Online Courses (MOOCs).

\subsection{Open Educational Resources}

First of all, it is Open Educational Resources: digitised materials offered freely and openly for educators, students and self-learners to use and reuse for teaching, learning and research [20. The development of the information society and the widespread diffusion of information technology give rise to new opportunities for learning. At the same time, they challenge established views and practices regarding how teaching and learning should be organised and carried out. Higher educational institutions have been using the Internet and other digital technologies to develop and distribute education for several years. Yet, until recently, much of the learning materials were locked up behind passwords within proprietary systems, unreachable for outsiders. The open educational resource (OER) movement aims to break down such barriers and to encourage and enable freely sharing content [13]. The term "OER" is not synonymous with online learning, eLearning or mobile learning. Many OER while shareable in a digital format - are also printable.

Let us mention briefly that it was the Massachusetts Institute of Technology that first talked about placing learning materials for free on the Internet in 2001. Soon after the term "Open Educational Resources" (as well as an abbreviation OER) emerged and was defined as: "educational resources, enabled by information and communication technologies, for consultation, use and adaptation by a community of users for noncommercial purposes" [24]. The trend towards sharing software programmes (open source software) and research outcomes (open access publishing) is already so strong that it is generally thought of as a movement. It is now complemented by the trend towards sharing learning resources - the open educational resources movement.

Using OER is not cheating; in fact, it can improve the quality of learning experiences by building on other people's work. Too often staff are creating learning materials for modules and courses that have already been developed elsewhere to an excellent standard.

Since this first initiative, the number of repositories storing OER has grown in number and constantly shifts. The institutions involved so far seem to be well-reputed internationally or in their countries. Attitudes are changing in education globally to promote the open sharing of educational courses and resources [3].

The nature of these open materials means that anyone can legally and freely copy, use, adapt and re-share them. OERs range from textbooks to curricula, syllabi, lecture notes and recorded lectures, essay questions and other assignments, tests, projects, audio, video and animation, discussion topics or reading lists. Teaching staff can "pick and mix" them to suit their own purposes [7].

That leads us to the role that institutional staff play in producing and (what is more important for our study) using the content. A number of studies conducted in European universities have explored staff attitudes towards OER [13]. Generally, the most significant barriers surrounding the use of OER included the lack of time and lack of a reward system. In Russia we add here staff attitudes to borrowing and sharing resources. A culture of borrowing and sharing of resources exists between close colleagues, but not further afield (something like "I only use resources recommended by someone I know and trust"), and whilst some teachers would obtain resources from the Internet, they are unwilling to place materials there saying: "Why give away resources to other universities?" Besides, the concept of open licensing with respect to content has arrived to Russia relatively recently: people producing and using intellectual products in Russia are predominantly familiar with the concepts of copyright and author rights and unaware or know very little about open licenses, the more so as the culture of sharing is not prevailing yet.

Another difficulty of using OER is that the openness of the resources is often limited by a language barrier. Most repositories are in English and university staff in Russia use and create their own cultural content in their own language. That is why advantages of OER and opportunities they offer to different levels of the educational system are not yet fully recognized.

As for the arguments supporting OER projects, they are as follows:

- OER expand access to learning for everyone but most of all for nontraditional groups of students and thus widen participation in higher education;

- They can be an efficient way of promoting lifelong learning for both the individual and the government;

- They can bridge the gap between nonformal, informal and formal learning.

Thus, OER projects expand access to learning for everyone, most of all for non-traditional groups of students and thus widen participation in higher education. They can be an efficient way of promoting lifelong learning. They can bridge the gap between non-formal, informal and formal learning. OER is itself a challenge (especially in Russia), but 
may also become a sound strategy for individual institutions to reimagine.

\subsection{Massive Open Online Courses}

In 2011, the respective roles of higher education institutions and students worldwide were brought into question by the rise of the Massive Open Online Courses. MOOCs are freely available, accessible and contain materials that are cleared for use in any educational or personal context.

The European Commission defines a Massive Open Online Course as: "an online course open to anyone without restrictions (free of charge and without a limit to attendance), usually structured around a set of learning goals in an area of study, which often runs over a specific period of time (with a beginning and end date) on an online platform which allows interactive possibilities (between peers or between students and instructors) that facilitate the creation of a learning community. As it is the case for any online course, it provides some course materials and (self) assessment tools for independent studying" [1]. These courses are offered mainly by universities, and, increasingly, institutions around the world are joining various MOOC platforms to offer their courses.

The literature on MOOCs is growing $[5,7,13$, 17]. This literature tends to acknowledge (with a few exceptions) that MOOCs bring an impetus of reform, research and innovation to the process of learning. For example, using a definition of MOOCs as courses which "are free of charge, open to a global audience and built for large numbers of people", Prof. M. Barber from Institute for Public Policy Research identifies the significant difference between MOOCs and prior forms of online learning as "this shift from depending on the government to focusing on the customer - in this case the student has played out again and again in other sectors as globalisation and technology have changed the rules of the game." [3]

American and European literature addressing MOOCs from the perspective of university education considers the pros and cons of MOOCs for universities, assesses the problems of MOOC production and delivery, forecasts MOOC impact on university models, and analyses trends [11]. However, there is little published discussion on MOOCs and their possible contribution to university education in Russia and some universities and their staff have not even heard about them.

Still, MOOCs offer university-level courses without the need to complete an entire program. They are ideal for unsupervised activities and other universities can select courses from any institution offering them to their students. There are very few face-to-face courses that include the flexibility of online access to lecture materials and recordings.
MOOCs provide an online version of a complete course, with video instruction, online quizzes and forums to encourage student engagement, virtual office hours where professors communicate with students, and graded assignments (using software or peer students to do the grading) to evaluate whether students learn from the course.

The main limitation of these distance-learning approaches is the fact that it only impacts those whose primary motivation is to acquire new knowledge and skills. In other words, this type of course is not very effective with those who are only motivated by obtaining credits. The MOOC format itself suffers from weaknesses around access, content, quality of learning, accreditation, pedagogy, poor engagement of weaker learners, exclusion of learners without specific networking skills.

Another problem here is that content from a MOOC offered by a university outside your students' home country may not match cultural and other conditions with which they are familiar. There may also be some issues for students who lack motivation [17]. Since a MOOC is voluntary and there is no penalty for dropping the program or lagging behind, there may be issues with course completion. Although a student may have received an excellent education, there will not be a corresponding diploma. Besides, MOOC certificates are not recognised by Russian universities at the moment, so MOOCs serve mostly for the purpose of self-education. Besides, Russian universities face here other problems, including the need to localize content by translating it from English into Russian and a difficult adjustment of online courses to Russian universities' curricula.

On the other hand, at a national level, MOOCs represents a further blurring of the borders between formal and informal learning, and universities are recommended to study how MOOCs can be efficiently used to meet some of the demand for increased lifelong learning.

\subsection{Shared Online Courses}

Shared Online Courses are high-quality online courses and learning modules that are broadly available for sharing across multiple institutions. The idea of SOCs comes from MOOCs as to share eLearning courses via a learning management system now is common [4].

Still there are differences here:

- A SOC is a combined effort of higher education institutes and not of an individual company or a prestigious university. Current approaches to reduce cost have a negative effect on quality and diversity (smaller studies disappear). Only by sharing resources this can be prevented. Resource sharing is not necessarily restricted to 
digital resources; also teachers can be shared, e.g. by using on-line classes or webinars.

- $\quad$ SOCs developed by a group of universities are good quality courses and materials positioned within their institutional branding and are available online for students of these universities only.

- SOCs also provide support for actual certification to be carried out by certain universities. Certification is probably the last service universities want to lose. That is the reason Shared Online Courses are not open.

The Russian Ministry of Education launched a national website as a gateway to open and distance learning, called the "Russian national platform of open learning" (available at: https://openedu.ru/) (see Figure 3). This initiative aims to present the various online offerings of Russian universities on one website, and to develop a platform for further development of high-quality online education in the country [22]. Its long-term goal is to make a full analogue of university's curricula which will allow to get knowledge of the same level and quality as during academic education. It implies high requirements to the developing programs and their effectiveness. Students will have an opportunity to successfully complete the basic education programs staying at home. This resource is expected to raise higher education to the next level and improve overall quality in regional universities and affiliated structures.

\section{Uтнрытое
образование}

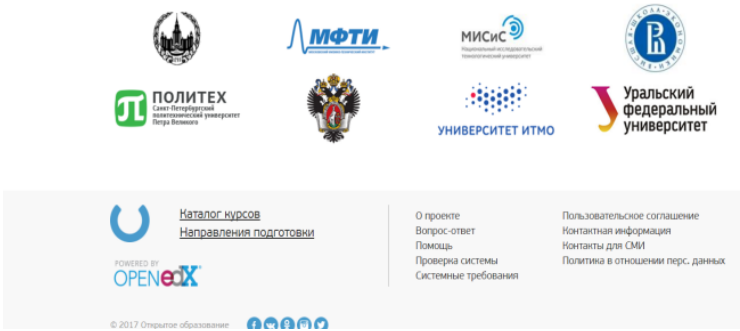

Figure 3. Russian national platform of open learning

The project started with eight of the leading Russian universities (among them National Research Nuclear University "MEPhI", Ural Federal University, Lomonosov Moscow State University, National University of Science and Technology MISiS, ITMO University, Saint Petersburg University and St. Petersburg Polytechnic University) - each of which initially offered four courses on the website. These universities hope that the establishment of a national educational online platform and the advancement of Internet education in universities will enable Russian universities to strengthen their positions in the area of higher education.

The platform, used for publishing online courses created by the members of the Association, facilitates the adoption of international standards, formulates its own requirements concerning the quality of online courses and collaborates with providers of higher educational programs, which are implemented using online courses hosted on the platform. Each course undergoes an internal expertise at a university, and a review by the Association to ensure compliance with the "Requirements and Recommendations for Online Courses on the National Open Education Platform", co-developed by members of the Association. In contrast to other on-line educational resource, Open Education is designed primarily for university students. Nearly all the offered courses are part of higher education programs and are compulsory modules in higher education curricula. Upon successful completion of the course, learners get a course certificate, and credits for the course can be counted towards the students' curriculum at any university in Russia. In the future, students will be able to master a major part of their university program online by taking courses on this platform. Since the teacher's role as supplier of reading lists and teaching materials is diminishing, SOCs are likely to accelerate changes in the traditional teaching role and the evolution of more independent learners. Most university authorities believe that the quality of education in Russia will grow thanks to the fact that any student from any Russian university will be able to take courses at top Russian universities wherever and whenever they choose.

Still now the choice of courses on the platform is limited (to 194 in fact). It is the goal of the Russian Ministry of Education and Science to incorporate more universities in this national open learning initiative and to increase the number of courses offered via this gateway; up to 250 courses by the end of 2017. For the time being, the Russian Ministry of Education is preparing to grant accreditation to courses taken on this platform by students of all Russian higher education institutions and is drafting new regulations to allow all Russian universities to include Open Education courses in their programs.

The ultimate goal of the program is to replace distance learning with online courses, improve the quality of education in universities and regional branches, make the educational process in Russia more modern, and improve students' computer skills.

Furthermore, the introduction of new technologies will enable the program creators to produce more research resources for universities and increase competition in higher education by enabling students 
and administrators alike to choose their online options in accordance with the suitability and quality of the courses.

\section{Conclusion}

Technology is becoming central to the process of learning and teaching in higher education and, in some countries, is driving wider access to education and training. As societies rapidly develop into knowledge-based information economies, information technology becomes a key driver of both economic competitiveness and social development. Fluency in information technology has thus become a central pillar of higher education - both implicitly in how information is shared and explicitly in preparing students for the global markets they will enter after graduation.

The current challenges facing traditional higher education, including higher tuition, budget cuts, and the gap between theoretical and practical training, have caused many universities to search for alternatives. Thus, online learning environments have come to the forefront of higher education. The options we choose are implementation of Open Educational Recourses, Shared Online Courses and Massive Open Online Courses into the educational process. All three offer new approaches to traditional campus-based teaching, with virtual learning environments used for course administration, storage of course content and additional resources. Still these new resources should be introduced gradually, while maintaining proper balance between introducing them and traditional education. Only on this condition will we create a new effective learning environment and increase students' satisfaction, better management of intellectual property, and community building.

\section{References}

[1] Alekseev, O., (2014). "First Steps of Russian Universities to Top-100 Global University Rankings", Higher Education in Russia and Beyond, No.1, pp. 6-7.

[2] Altbach, P.G., Reisberg, L., Rumbley, L.E., (2009). "Trends in global higher education: Tracking an academic revolution." A report prepared for the UNESCO 2009 World Conference on Higher Education, 2009, available at: http://www.uis.unesco.org/Library/Documents/trendsglobal-higher-education-2009-world-conference-en.pdf (Access date: 10 November, 2016), 278 p.

[3] Anderson, T., Dron, J., (2011). "Three Generations of Distance Education Pedagogy in International Review of Research in Open and Distance Learning”, Athabasca University, Vol. 12.3, pp. 80-97.

[4] Baaren, J. van der, (2015). "Cheaper, better and more relevant Higher Education using Shared Online Course", Open Education 2030, pp. 8-10.
[5] Barber, M., Donnelly, K., Rizvi, S., (2013). "An avalanche is coming: Higher education and the revolution ahead", London, Institute for Public Policy Research, available at: http://www.ippr.org/publication/55/10432/anavalanche-is-coming-higher-education-and-the-revolutionahead (Access date: 23 December, 2016), 78 p.

[6] Bozkurt, A., Aydın, C., (2015). "Satisfaction, Preferences and Problems of a MOOC Participants, Proceedings of The Association for Educational Communications and Technology" AECT International Convention, pp. 35-41.

[7] Butcher, N. (2011). "A Basic Guide to Open Educational Resources (OER)", Vancouver: Commonwealth of Learning, $134 \mathrm{p}$.

[8] Crose, B., (2011). "Internationalization of the Higher Education Classroom: Strategies to Facilitate Intercultural Learning and Academic Success", International Journal of Teaching and Learning in Higher Education, Volume 23, No. 3, pp. 388-395.

[9] European Commission, (2014). "Report on Web Skills Survey: Support services to foster Web Talent in Europe by encouraging the use of MOOCs focused on web talent", D1.1, First Interim Report, available at: http://openeducationeuropa.eu/sites/default/files/MOOCsfor-web-skillssurvey-report.pdf (Access date: 1 December, 2016), $20 \mathrm{p}$.

[10] Federal State Statistics Service, (2016). "Russian yearbook of statistics", available at: http://www.gks.ru/bgd/regl/b16_13/Main.htm (Access date: 1 April, 2016).

[11] Feldmann, B., Schlageter, G., (2011). "Five Years Virtual University - Review and Preview", World Conference on WWW and Internet Proceedings Orlando, Florida, Oct. 2011, pp. 23-27.

[12] Frumina, E., West, R., (2012). "Internationalisation of Russian Higher Education: the English language dimension", British Council, 83 p.

[13] "Giving Knowledge for Free: the emergence of open educational resources", (2007). Organisation for Economic Co-Operation and Development publications, France, available at: www.sourceoecd.org/education/ 9789264031746 (Access date: 3 December, 2016), 153 p.

[14] Gounko, T., Smale, W., (2007). "Modernization of Russian higher education: exploring paths of influence", Routledge, Journal of Comparative Education, Vol. 37, No. 4, pp. 533-548

[15] Haggard, S., (2013). "The Maturing of the MOOC: Literature review of Massive Open Online Courses and other forms of online distance learning", available at: https://www.gov.uk/government/uploads/system/uploads/a ttachment_data/file/240193/1 3-1173-maturing-of-themooc.pdf (Access date: 1 December, 2016) 123 p.

[16] Halic, O., Greenberg, K., \& Paulus, T. (2009). "Language and academic identity: A study of the 
experiences of non-native English speaking international students", International Education, 38(2), pp 73-93.

[17] Hanson, J., (2010). "Displaced by not replaced: the impact of e-learning on academic identities in higher education", Teaching in Higher Education, 14 (5), pp. 553564.

[18] International Trends in Higher Education 2016-17, University of Oxford, available at:http://www.ox.ac.uk/ sites/files/oxford/trends\%20in\%20globalisation_WEB.pdf, (Access date: 2 April, 2017), p. 24.

[19] Kalman, Y.M., (2015). "A race to the bottom: MOOCs and higher education business models", Open Learning: The Journal of Open, Distance and e-Learning, 29(1), pp. 5-14.

[20] Mossley, D., (2014). "Open Educational Resources and Open Education", The Higher Education Academy, York Science Park, Heslington, $26 \mathrm{p}$.

[21] Nikolaev, D., Chugunov, D., (2012). "The Education System in the Russian Federation", Education Brief, International Bank for Reconstruction and Development, Washington, $100 \mathrm{p}$.

[22] Sigalov A., Skuratov A., (2012). "Educational Portals and Open Educational Resources in the Russian Federation", Federal Research Institute of Information Technologies and Telecommunications "Informika", Moscow, $45 \mathrm{p}$.

[23] Tuomi, I., (2013). "Open Educational Resources and the Transformation of Education", European Journal of Education, 48 (1), pp. 58-78.

[24] United Nations Educational, Scientific and Cultural Organization (UNESCO), (2002). "Forum on the Impact of Open Courseware for Higher Education in Developing Countries", Final Report, available at: http://unesdoc.unesco.org/images/0012/001285/128515e.p df. (Access date: 25 August, 2016), p. 30.

[25] Zawacki-Richter, O., Kondakci, Y., Bedenlier, S., Alturki, U., Aldraiweesh, A., Püplichhuysen, D., (2015). "The Development of Distance Education Systems in Turkey, the Russian Federation and Saudi Arabia", European Journal of Open, Distance and e-Learning - Vol. 18 / No. 2 (113), pp. 113-129. 